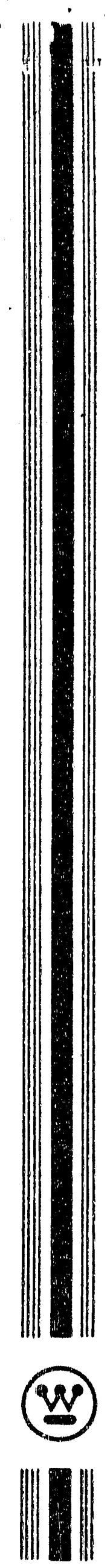

\author{
PERFORMANCE EVALUATION OF A CERAMIC CROSS-FIOW FIITER \\ ON A BENCH-SCALE COAL GASIFIER
}

Westinghouse Principal Investigators

D. F. Clilberti and T. E. Lippert

DOE Project offlcer: Randall J. Dellefleld

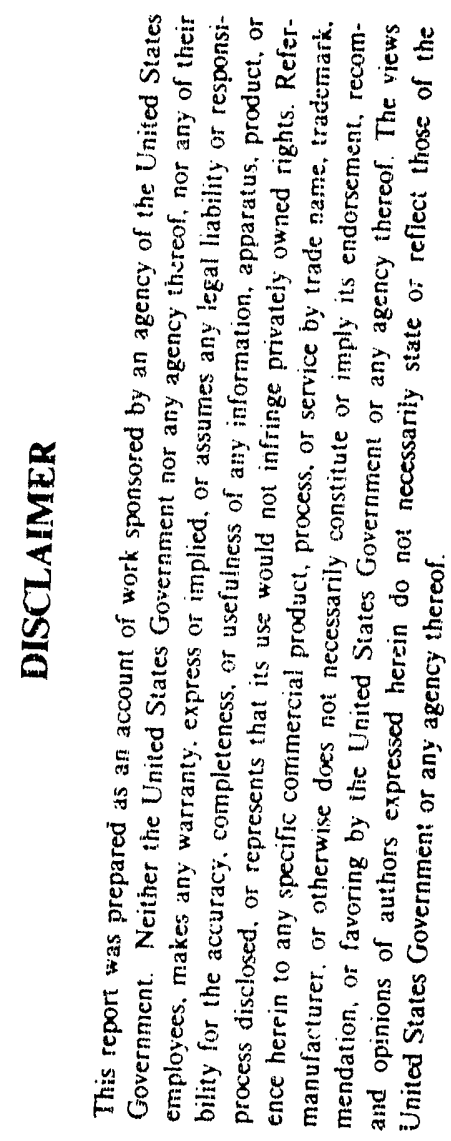

Morgantown Energy Technology Center

First Quarterly Profect Report

octoior 1, 1984 - December 31, 1984

Contract Number DE-AC21-84MC2 1338

Department of Energy

\author{
P.O. BoX 880 \\ Collins Ferry Road \\ Morgantown, WV 26505
}

uorgantown, MV 26505 


\section{PERFORMANCE EVALUATION OF A CERAMIC CROSS-FLOW FIITER ON A BENCH-SCALE COAL GASIFIER}

Westinghouse Principal Investigators

D. F. Ciliberti and T. E. Lippert

First Quarterly Project Report October 1, 1984 - Decembis 31, 1984

Contract Number DE-AC21-84MC2 1338

DOE Project Officer: Randall J. Dellefield

Department of Energy

Morgantown Energy Technology center

P.o. Box 880

Collins Ferry Road

Morgantown, WV 26505 
DISCLAIMER

This report was prepared as an accourt of work sponsored by the United States Government. Neither the United states nor the United States Department of Energy, nor any of their employees, makes any warranty, express or implied, or assumes any legal ilability or responsibility for the accuracy, completeness, or usefulness of any information, apparatus, pr luct, or process disclosed, or represents that its use would not infringe privately owned rights. Reference herein to any specific commercial product, process, or service by trade name, mark, manufacturer, or otherwise, does not necessarily constitute or imply its endorsement, recommendation, or favoring by the United States Government or any agency thereof. The views and opinions of authors expressed herein do not necessarily state or reflect those of the United states Government or any agency thereof.

PATENT STATUS

This technical report is being tansmitted in advance of DOE patent clearance and no further dissemination or publication shall be made of the report without prior approval of the DOE Patent Counsel.

\section{TECHNICAL STATUS}

This technical report is being transmitted in advance of DOE review and no further dissemination or publication shall be made of the report without prior approval of the DOE Project/Program Managex. 
The Department of Energy is currently supporting a program that will aid in the development of cross flow filtration technology as applied to combined cycle power generation with coal gasification. The stated overall goal is to gain information on both the operational and economic. feasibility of the implementation of cxoss flow filtration in various gasifier options. Westinghouse has prepared a comprehensive program that will lead directly to these program goals in an efficient manner.

The proposed program is composed of three major technical tasks. Task $I$ is directed at the design and actual test of a cross flow filter at a DOE bench scale gasifier. Task 2 is composed of several smaller theoretical and experimental efforts that are intended to firm up areas where engineering and design principles are lacking or considered inadequate. The third task is intended to integrate the results of the first two tasks in a conceptual design and cost analysis such that proper economic perspective for the filter concept can be gained. A brief summary of the approach taken in the technical tasks is presented in the following aiscussion.

In the conduct of Task 1 , we will design, fabricate, install, and operate a cross flow test system at the AGC. The actual test article will incorporate provisions for a scaled down cross flow element that will accomnodate all of the gasifier flow. From this element, we will gain information on filtration parameters such as efficiency, pressure dxop, and cleanability. The element will be instrumented with high speed differential pressure transducers that will allow us to quantify the pulse jet parameters that are required for successful blow back cleaning. These will subsequently serve as inputs to scaling models for full size module calculations. 
In Task 2 we propose to conduct a series of independent tests. The efforts center on the following areas: 1) a task to develop a filter element with improved mounting and delamination properties, 2) a task to refine our model that describes the dynamics of pulse jet cleaning, 3) a task to quantify the dust cake properties of char and sulfur sorbent fines, and 4) a chemical stability test of the cross flow filter in a simulated gasifier environment.

The third technical task will involve the integration of new test data and model refinements into a sound conceptual design for at least three gasifier systems. Westinghouse personnel that have had past and current responsibility for commercial gasification systems design and cost analysis will assume the primary responsibility for this task. We are confident that the approach of coupling a sound scientific data base and scaling methodology with a broad systems understanding and capability will result in a sound conceptual design and costing basis. 
PROJECT SUMMARY FOR FIRST QUARTERLY REPORT

October

Westinghouse and DOE completed contract negotiations for the cross flow filter program and the contract was awarded and made effective on october 1 , 1984. Due to several last minute changes in the negotiated fee and provisional overhead rates it was not possible to process the contract through the westinghouse contracts and the management signature route before the end of october. The result of this was that no valid change numbers were established by our accounting department until the week ending November 4, 1984. With no charging mechanism in place, virtually no engineering activity was begun in this month. The consequence of this annoying delay could not be determined until a testing schedule was established by DOE and the three contractors. In December a tentative schedule was established calling for installation of the Westinghouse device first, and in a time frame of June 1 , 1985. There has been recognition that this schedule will provide minimal test time for qualification of test elements from either coors or GTE sylvania.

November

During November efforts directed at the filter vessel design were initiated. Early on a consensus was reached with DOE personnel to abandon the earlier plan for a large static filter element mounted in parallel with a smaller working element. A "first cut" layout drawing of the vessel and internals was provided to DOE for comment and feedback. After some interaction a second revision of the design was produced. This drawing along with a prelininary P\&ID were used for discussion and planning purposes at the initial contractor's meeting at Morgantown. During this 
time a short computer program was developed to calculate heat loss for the system and this was used to provide input to DOE on possible problems in the hot gas piping run to the test vessel.

Another task begun in November was an attempt to get the filter suppliers, GTE Sylvania and coors Porcelain, on board and up to date on the goals of the program. Site visits to each supplier took place in November. Agreement was reached on what was required from each supplier and how each party was to proceed. Contractual formats were also agreed upon and efforts were initiated at westinghouse to implement working arrangements with each supplier.

\section{December}

\section{Filter supply}

During the month of December the efforts directed at filter element supply consisted only of preparation of Purchase order Forms with appropriate terms and conditions. Plant shut-downs at vendor sites made more progress difficult, however, the information required to issue purchase orders for filter supply was given to Westinghouse Contracts Management personnel so that purchase orders could be issued prior to the holidays.

\section{Vessel Design and Testing}

During early December a meeting of all three DOE contractors and DOE project personnel was held at Morgantown. At this meeting a consensus was reached on the elements of vessel design that would be the same for all three contractors. These consisted of such things as inlet pipe elevation, flange sizes and dust hopper provisions. The agreed upon modifications were incorporated in a 
revised vessel drawing for the cross flow filter, and an assembly drawing has been provided to Westinghouse purchasing personnel in order that they be able to obtain competitive quotes for the supply of the vessel. These drawings were provided to Westinghouse contract Administration personnel soon after the Morgantown meeting so that requests for quote on fabrication could be sent out to machine shops prior to christmas. The drawings have also been provided to DOE for further comment, in preparation for a safety review.

Blow Back System Design/Analysis

The blow back system design and analysis task consists of two efforts, one experimental in nature and the other a more theoretical modeling effort. R\&D personnel for both of these tasks have been identified and approval for their input has been obtained. It is expected that both efforts will be started in earnest after the holidays.

\section{Contract Management and Reporting}

The preliminary contract management reports such as the program management plan have been prepared and have been given to NTD Contract Management personnel for final printing, publication, and submission to DOE. 


\section{QUARTERLY TECHNICAL PROGRESS REPORT}

\section{TASK 1 - Vessel Design and Testing}

Work on a preliminary vessel design was begun in early November. In concurrence with the cognizant DOE technical personnel a decision was made to not proceed with the original plan of a parallel arrangement of a small active filter and large inactive or static filter (Fig.1). It was decided that the large static filter unit (designed for pulse tests) might represent a significant potential for causing test difficulties in the primary (active) filter unit. In view of this decision a "first cut" design of the filter vessel housing vessel was prepared and submitted to DOE for comment and feedback. This basic design is presented in Figure 2. Subsequent to this effort, several phone conversations with DOE and one site visit at Westinghouse occurred as DOE project personnel worked to integrate their in-house design and system constraints into a format that was consistant and compatible with the requirements of the three contractors.

$$
\text { These efforts led to a second revision of the }
$$

cross flow vessel design showr in Figure 3 . This figure and a preliminary P\&ID for the filter served as the basis for planning and discussion in a joint meeting of the DOE and their three contractors which was scheduled for $12 / 11 / 84$ at Morgantown. As part of this early interactior with DOE, Westinghouse provided some design calculations and input on potential problems with heat loss in the piping run from the DOE gas heater and the test vessels.

In early December a meeting of the three contractors and DOE personnel was held at Morgantown for the purpose of agreeing on several design characteristics 


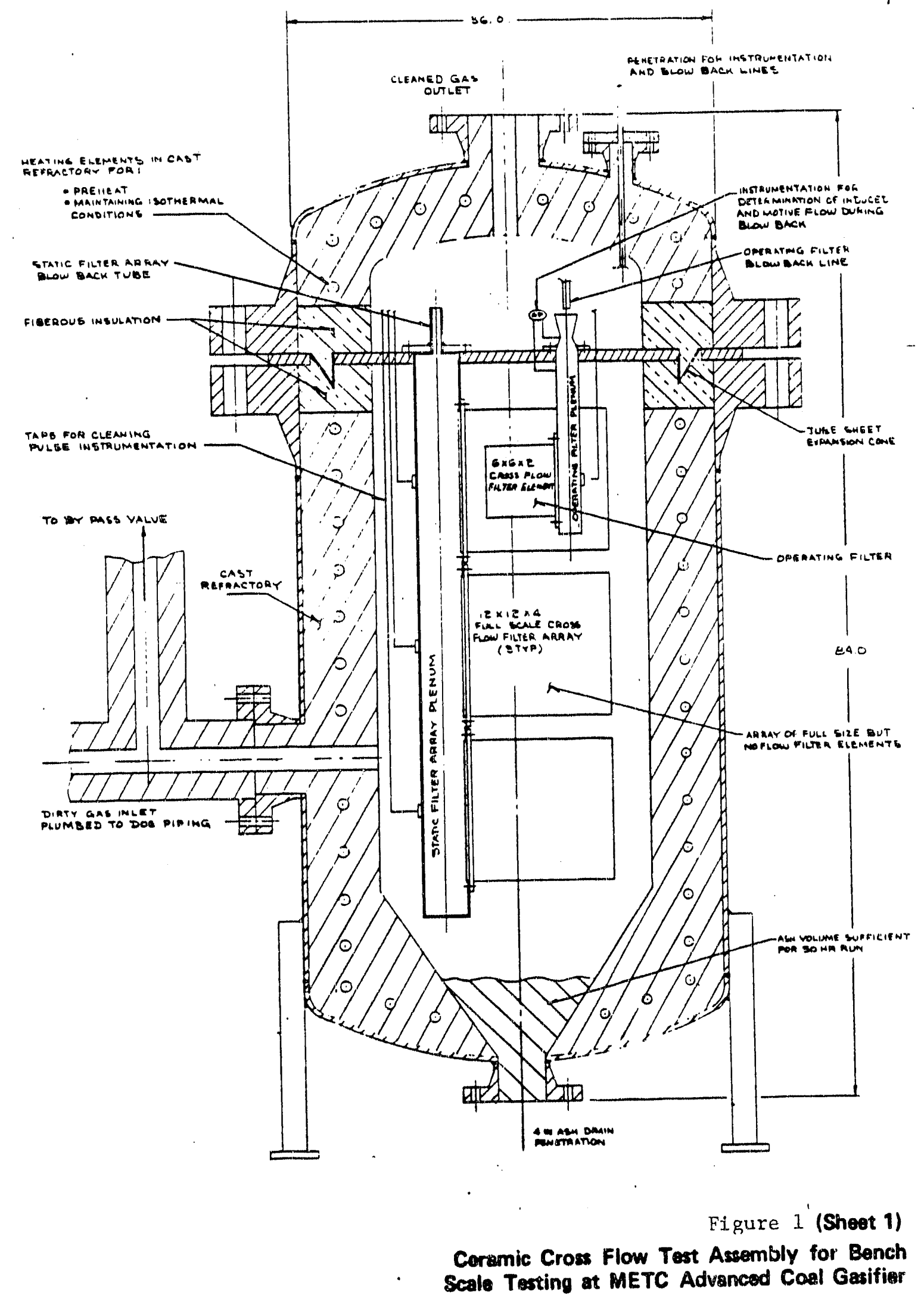




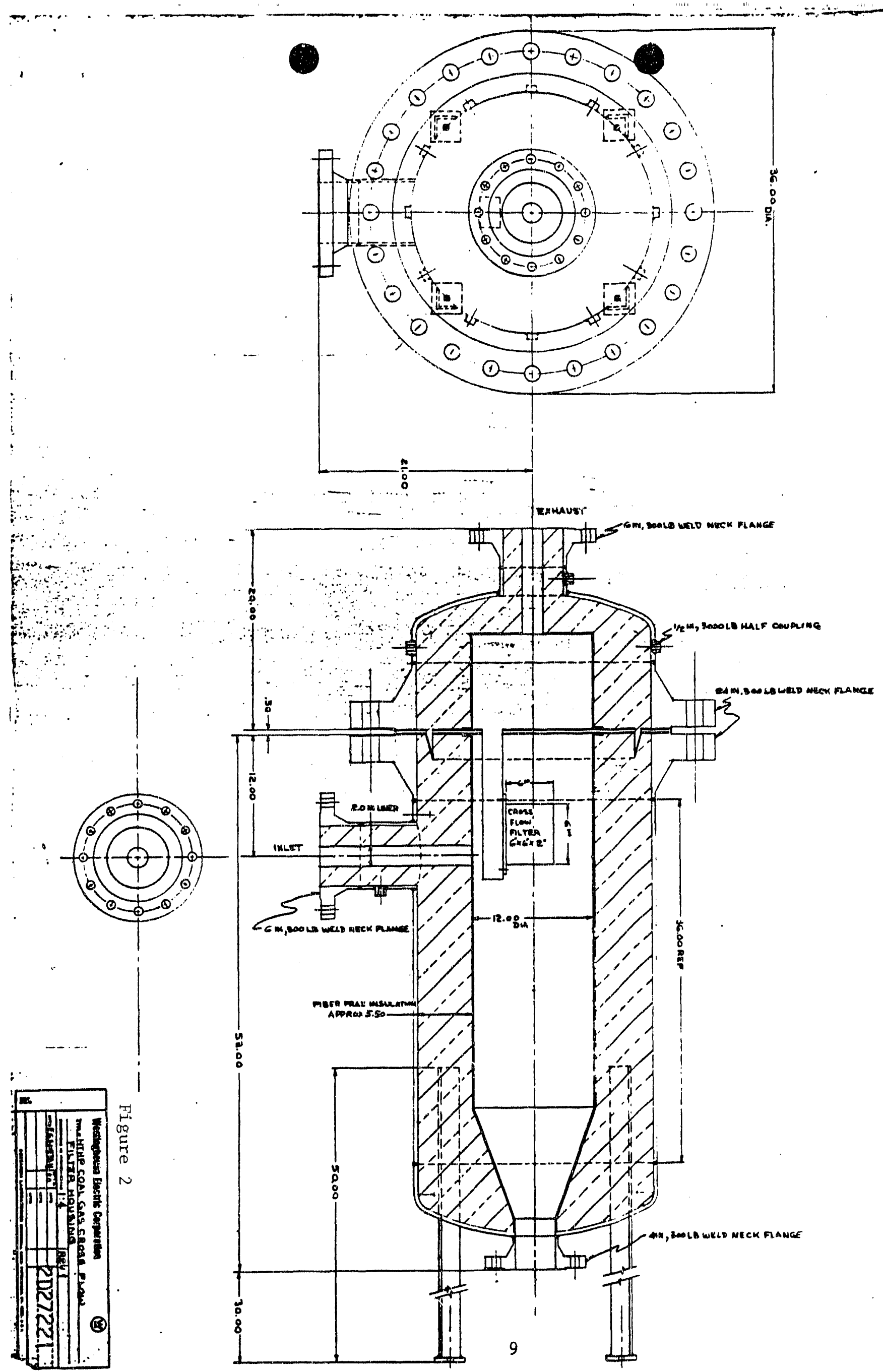




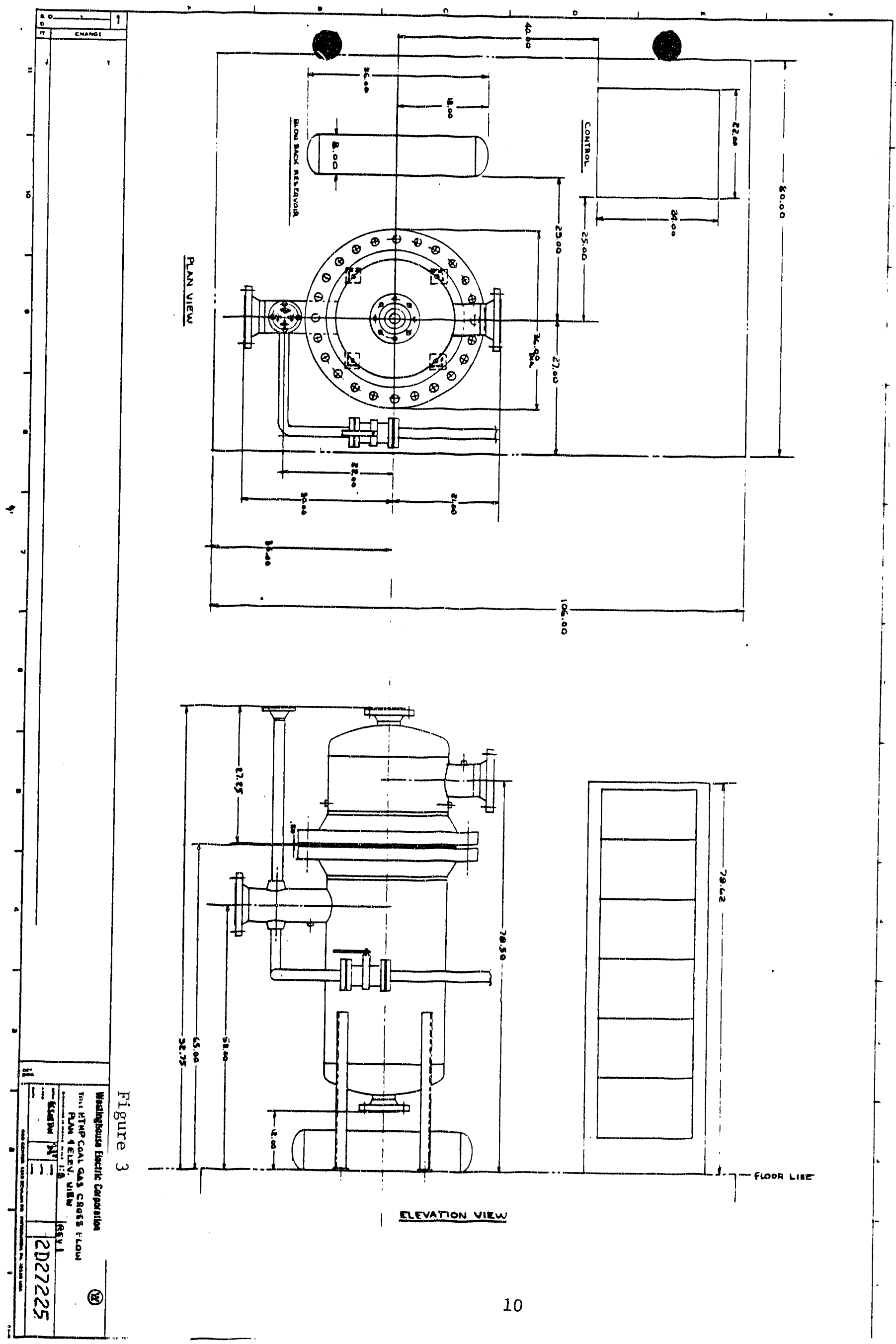


common to all three contractors' designs. This meeting was most helpful in establishing such things as uniform piping and flanging, as well as discussing requirements for system by pass and ash hopper provisions. Attachment 1 lists DOE's summary of items agreed upon as a design basis, and which demark the areas of contractor/DOE responsiblitity for systems and guipment.

These agreed upon design aspects were incorporated into the Westinghouse cross flow filter test vessel dusinn and Figure 4 presents a layout of the current. design. Although the detal:s of the vessel internals were not completed, sets of this drawing were submitted to the Westinghouse NTD purchasing department so that fabrication shops could prepare competitive bids for the supply of the pressure shell. It is our intention to fabricate the internals "in-house" and install the insulation, heatexs, Iner and tubesheet/filter mounting assembly ourselves. We currently have draftsmen detailing the internals and filter inounting systern.

During the Morgartown meeting there was a clear consensus among the contractors that a larger flow of test fuel gas would be desirable. DOE operation personnel have agreed to investigate the possibility of providing a 5 fold increase in flow to aximum value of $5000 \mathrm{scfh}$. At his pint we do not anticipate that this change will impact the vessel design for the cross flow filter since, even the smallest filter unit can accomodate this flow.

In order to facilitate safety and operating procedure documentation a preliminary P\&ID fer the cross flow filter has been prepared and is presented in Figure 5. This sketch is helpeul in ldentifying the instrumentation and hardware interfaces for the Westinghouse anC DOE systems. This diagram is based on the most current DOE system P\&ID for the overall system, and emphasizes the filter unit and 1ts subcomponents. 
홍
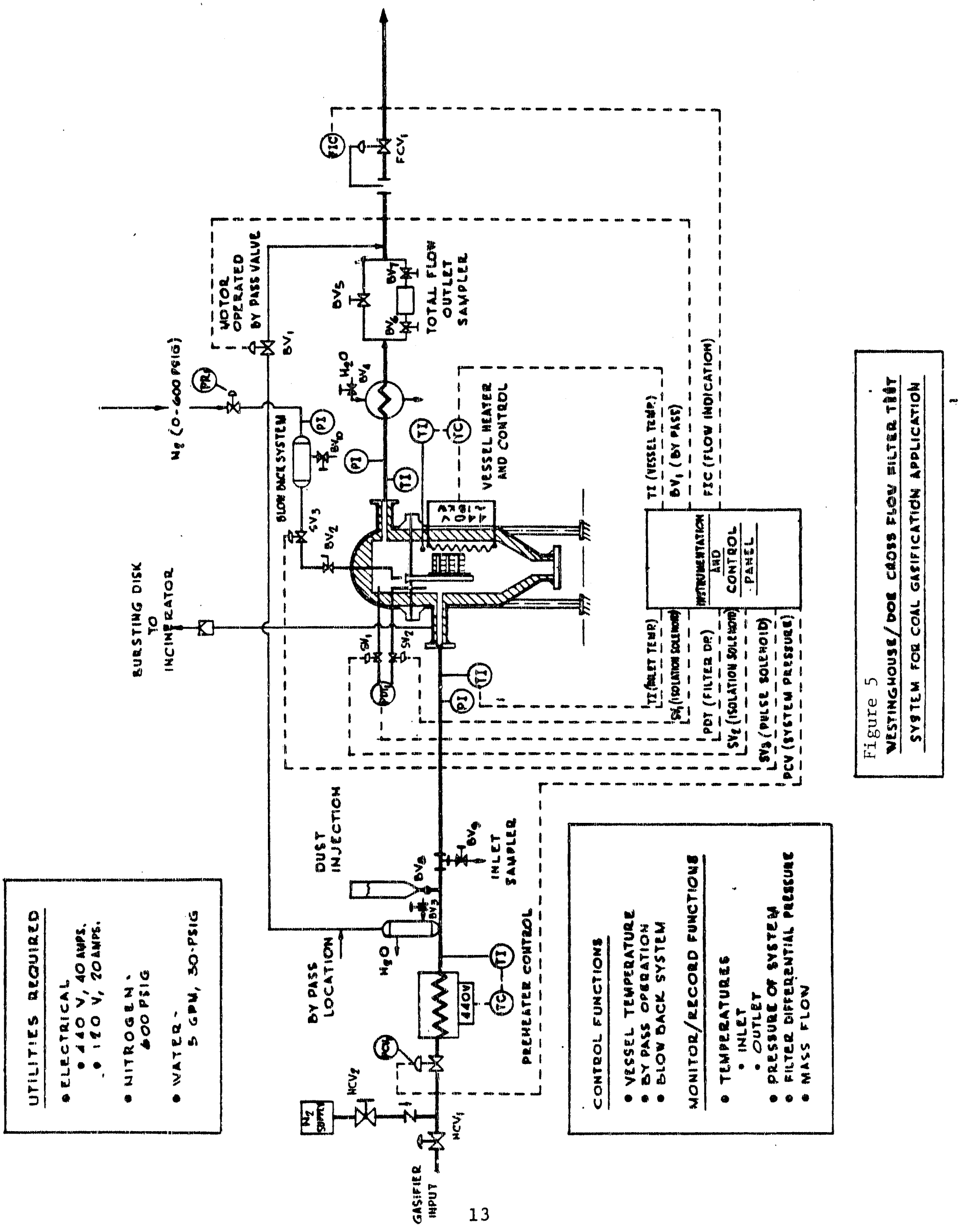


\section{TASK 2 - Design Principles Development}

\section{Blow Back system Modeling}

The task designed to investigate the dynamics of filter element pulse jet cleaning is composed of two efforts, one theoretical in nature and the other an experimental component intended to calibrate and test the modeling effort. In a previous program a computer model was developed for this purpose, but several possible enhancements have been developed since the original work. In particular, the inclusion of an induced flow component is known to be of importance, and appears to be possible to include in the model

An additional goal of this work is the determination of groups of geometric and operating parameters that are importnt in scaling exercises, and which give the designer at least qualitatire measures of the effects of various parameter choices. Insights into the parameters controlling the cleaning of vag filter systems have been gained by such exercises and it is expected to be of value for the cross flow system as well.

\section{Filter Element supply}

During the perlod of time during which Westinghouse was preparing their proposal for the cross flow filter work, both GTE Sylvania and Coors porcelain Co. had indicated a desire and willingness to work with Westinghouse on the development of cross flow filter technology. The Westinghouse project manage visited each site late in November to familiarize each supplier with the details of the test program and to initiate whatever 
contractual actions that were required. Each supplier was given the preliminary specifications shown in Table $I$ as a reference point for their efforts.

The GTE tech:rology for fabricating cross flow ceramic shapes basically consists of an extrusion process to obtain the ribbed structure in the "green" unfired state. This material is then chopped and stacked in the proper configuration for firing. GTE has made extensive use of bonding agents to improve their structure's resistance to delamination. Conversation with GTE technical people indicates a feeling that porosity control should be relatively easy to do but that the request by Westinghouse for a means of incorporating flanges on the ceramic body would be difficult because of the nature of the extrusion process. After some careful consideration a means of effectively flanging the GTE elements using a number of metallic tabs in the front, mounting face was devised, (see Figure 6) and Westinghouse has begun plans to proide this type of mounting. Another approach (resulting in a ceramic flange) has been devised by GTE and is currently being investigated.

Contractual discussions revolved around whether a formal subcontract or a purchase order agreement would be better. A decision was made to proceed with an initial purchase order (which can be processed relatively quickiy) and to follow that with a subcontract.

The coors technology for the manufacture of the cross flow shape is greatly different from the GTE extrusion process. Coors actually presses $1 / 2-3 / 4$ inch thick plates of the green powdered raw materials and then machines the ribbed structure into the plate. This process gives coors the added flexiblilty of incorporating a flange structure into their "green" body which would 
Table 1

\begin{abstract}
NOMINAL SPECIFICATIONS FOR CROSS FLOW CERAMIC FILTER ELEMENTS
\end{abstract}

Westinghouse/DOE Project for Hot Gas cleaning in coal Gasification Application

$11 / 29 / 1984$

Element supplier

Flanged Face

overall Element Size

Cell size

Back Wall Thickness

Rib Thickness

Pore size (bubble pres test)

Porosity
Coors

$1 / 4^{\prime \prime} \times 1 / 4^{\prime \prime}$

A) 12 " $\times 1211 \times 4 "$

B) $6 " \times 6 " \times 2 "$

$.15^{\prime \prime} \times .5^{\prime \prime}$

.0601

$.060 "$

100 micron

$35-408$ 


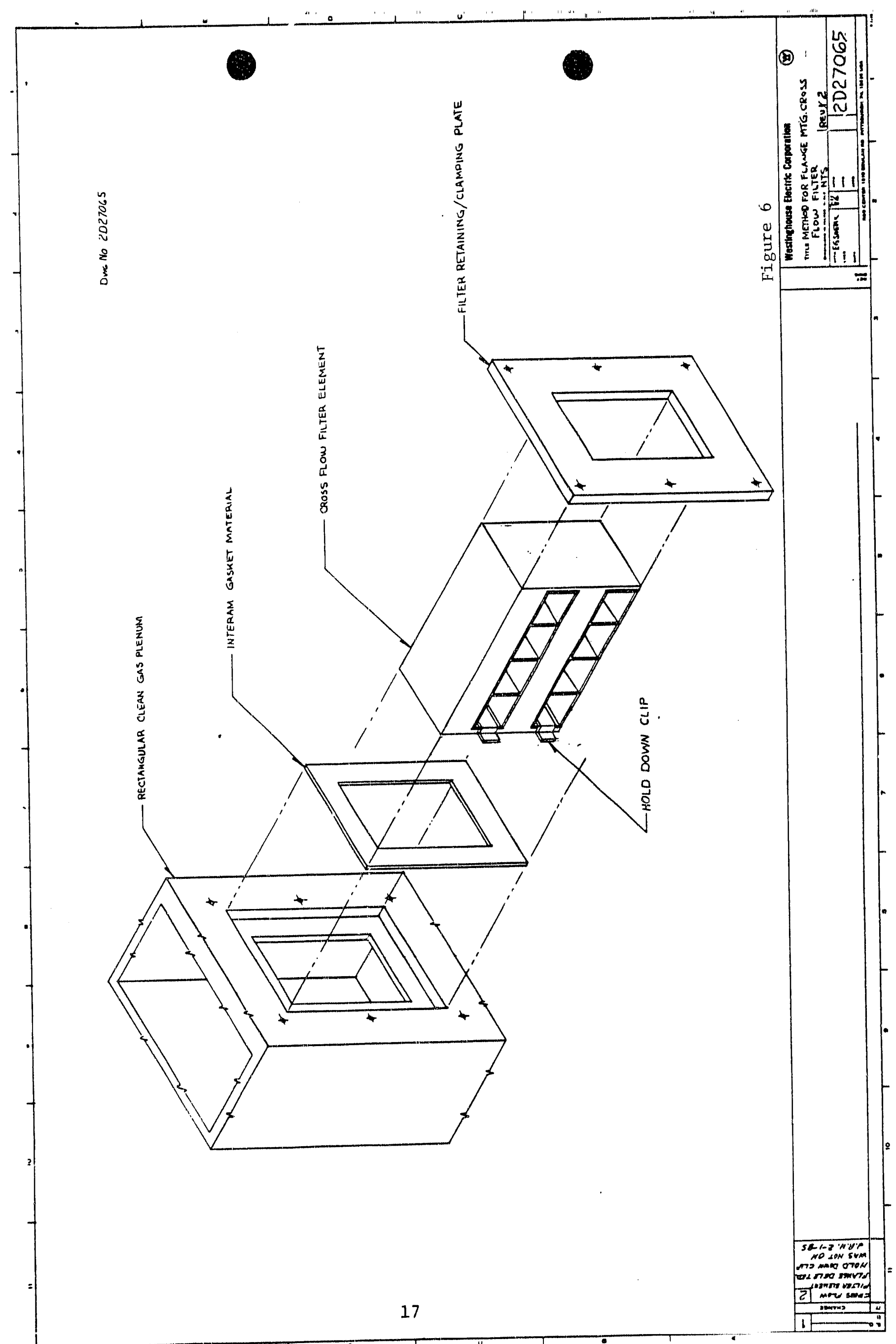


result in an integral ceramic flange in their filter elements.

Contractually coors prefers to continue on a purchase order for specified materials in the same fashion as the previous contract. 


\section{ATTACHMENT 1}

Items which were agreed upon in the progress and coordination meeting held here at METC on December 11, 1984. The following individuals and the organizations they represent were in attendance:

R. Dellefield, K. Markel and R. Bedick - Utilization \& Energy Conversion, METC

E. Oldaker and B. Rahfuse - Experimental Science Branch, METC

J. Rotunda - Instrumentation Science Branch, METC

$R$. Chang and J. Sawyer - Acurex

G. Rinard and J. Armstrong - Denver Research Institute

D. Ciliberti - Westinghouse

The meeting consisted of each contractor presenting the design philosophy of his test module and specifics of the pressure vessel. design. The inlet and outlet elevations, flange sizes, test requirements, and other items were resolved. The following list summarizes the items agreed upon.

Summary of Items agreed to in December 11, 1984 Progress Meeting

Items agreed to by all contractors and DOE:

1) System pressure for the test modules will be controlled upstream of the auxiliary heater. Pressure control will use the METC pressure tap prior to the test modules. Flow control will be conducted after the test modules.

2) METC will investigate the possibility of reducing particulate drop out in the transfer line from B-12 to B-4 by substantially increasing the flow from the gasifier to B-4. Increasing the flow above the planned 1000 scfh maximum will correspondingly increase the inpipe gas velocity, and thus keep more particulate in the gas stream. METC will investigate the possibility of providing a variable flow rate between the range of 2000 scfh to 5000 scfh, along with the possibility of bringing an estimated 8000 scfh of fuel gas to B-4 and then diverting to the incinerator (on top of the 42-inch Fixed Bed Gasifier) any excess gas which is not needed at the test modules.

3) The inlet of all three test modules will face the east wall (the wall with the two insulated 1 1/4-1nch gasifier fuel gas lines) and the inlet/outlet arrangement will be 180 degrees apart, parallel to the long axis of the bullding.

4) Inlet and outlet flanges will be 8-inch, 300-pound Raised Face. Holes will be straddled on the center line. Each contractor will be responsible for providing enough flexitalic gaskets to meet any likely contingencies.

5) METC will inltiate preliminary engineering to install a common hopper for all three test modules. This hopper will extend from the floor of the third level down to the second level. The hopper will be sized to handle the quantity of dust expected for a 50-hour run and will be purged with nitrugen for safety considerations. If the preliminary engineering does not indicate any problems with this concept, METC will construct the hopper while it is constructing the other facilities. 
6) To provide a common mate to the dust hopper discussed above, all three contractors will make the bottom flange of their test module a 6-inch, 300-pound Raised Face flange. If insulation is included in the flange iolnt then the internal diameter should not be less than 4 inches, and the internal slope of the cone should be at least 70 degrees. The distance between the bottom flange's face and the grating should be minimized to reduce the amount of adjustment METC will have to make when fitting the hopper to each test module.

7) The distance from the face of the inlet flange to the pressure vessel centerline will be 24 inches.

8) The centerline of the inlet flange will be elevated seven feet above the top surface of the floor grating.

9) The distance from the face of the outlet flange to the pressure vessel centerline will also be 24 inches.

10) METC will adjust the height of the piping to the outlet flange of the test modules.

11) Rupture disks or pressure control devices should be sized to handle the full flow of fuel gas. This flow rate will be determined in item ll $^{2}$ above. METC will meet the flange provided by the contractor to conduct the vented fuel gas to the incinerator. To eliminate excess custom fitting when the test module is delivered to METC, it is important that detailed drawings be prepared showing the size, location, height, and capability of the pressure control device.

12) Bypass line will be provided by METC. The bypass valve will be a moderate temperature (1000-1200 F) valve which will be motor actuated. The valve will be normally closed, Fall. Open, and controlled by a contact closure signal. If the particle feeder can be momentarily shut of $f$ the contact closure signal will also be used to tum the feeder off for the couple of seconds necessary to pulse clean the control device. If it is determined that the particle feeder can be interrupted momentarily, the bypass line will be arranged so it is taken off between the auxillary heater and the particle feeder.

13) The size, and power arrangements of each contractors control panel need to be submitted to facilitate final layout arrangement.

14) Any temperature data other than the inlet and outlet temperature data collected by the METC ADACS system which the contractor feels is necessary for successful completion of the test program will be collected and recorded by the contractor. 
15) Pressure instrumentation will be provided by METC on the Inlet and outlet lines. METC will provide access to the pressure instrumentation signals to allow separate recording and display on contractors control panels.

16) Contractors requiring delta pressure controls for cleaning requirements will provide those controls and instrumentation.

17) METC will provide particulate sampling of inlet and outlet gas streams. Currently it is estimated that 3 hours per sample will be required, with at least one hour extra to allow for cooling of the ceramic sampling thimble. Sampling will be conducted at the frequency specified in each contractors detailed test procedure.

18) Data required from METC will consist of particulate loadings, inlet and outlet particle size distributions of selected samples, fuel gas conpositions, coal analyses, and ash/char analyses.

19) METC will investigate auxiliary particle injection techniques which will minimize the dilution (or cooling) of the fuel gas. The use of only fuel gas as a particle carrier medium will be examined. 


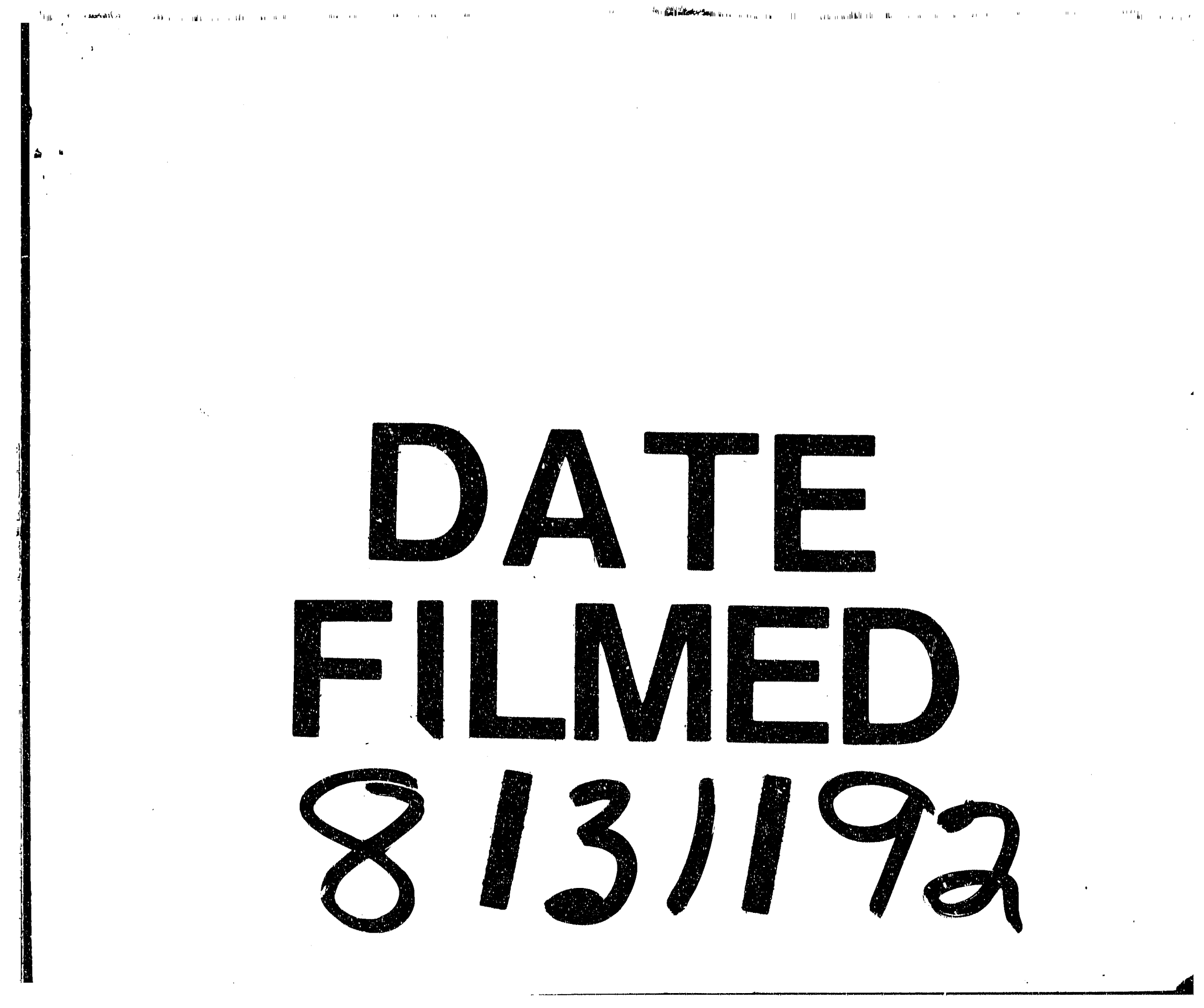


